\title{
Correction to: The effect of the sagittal plane osteotomy inclination on the posterior tibial slope in medial open wedge HTO: experimental study with a square column model
}

Sang Won Moon ${ }^{1}$, Ji Young Ryu ${ }^{2}$, Sung-Jae Lee ${ }^{3}$, Sang Won Woo ${ }^{3}$, Sin Hyung Park ${ }^{4}$ and Young Choi ${ }^{{ }^{*}}$

Correction to: BMC Musculoskelet Disord 22, 89 (2021)

https://doi.org/10.1186/s12891-021-03951-0

Following the publication of the original article [1] the authors found that panels $b$ and $d$ in Fig. 3 have the same image. The original article [1] has been updated.

The correct Fig. 3 is shown below.

\begin{abstract}
Author details
'Department of Orthopedic Surgery, Inje University Haeundae Paik Hospital, Gimhae, South Korea. ${ }^{2}$ Department of Occupational and Environmental Medicine, Inje University Haeundae Paik Hospital, Busan, South Korea. ${ }^{3}$ Department of Biomedical Engineering, Inje University, Busan, South Korea. ${ }^{4}$ Department of Orthopedic Surgery, Soonchunhyang University School of Medicine, Bucheon Hospital, Bucheon-si, Gyeonggi, South Korea.

${ }^{5}$ Department of Orthopedic Surgery, Kosin University Gospel Hospital, 262, Gamcheon-ro, Seo-gu, Busan 49267, South Korea.
\end{abstract}

Published online: 23 March 2021

\section{Reference}

1. Moon SW, Ryu JY, Lee SJ, Woo SW, Park SH, Choi Y. The effect of the sagittal plane osteotomy inclination on the posterior tibial slope in medial open wedge HTO: experimental study with a square column model. BMC Musculoskelet Disord. 2021;22(1):89 https://doi.org/10.1186/s12891-021-03 951-0.

The original article can be found online at https://doi.org/10.1186/s12891021-03951-0

*Correspondence: yuzo0n@naver.com

${ }^{5}$ Department of Orthopedic Surgery, Kosin University Gospel Hospital, 262, Gamcheon-ro, Seo-gu, Busan 49267, South Korea

Full list of author information is available at the end of the article

(c) The Author(s). 2021 Open Access This article is licensed under a Creative Commons Attribution 4.0 International License, which permits use, sharing, adaptation, distribution and reproduction in any medium or format, as long as you give appropriate credit to the original author(s) and the source, provide a link to the Creative Commons licence, and indicate if changes were made. The images or other third party material in this article are included in the article's Creative Commons licence, unless indicated otherwise in a credit line to the material. If material is not included in the article's Creative Commons licence and your intended use is not permitted by statutory regulation or exceeds the permitted use, you will need to obtain permission directly from the copyright holder. To view a copy of this licence, visit http://creativecommons.org/licenses/by/4.0/ The Creative Commons Public Domain Dedication waiver (http://creativecommons.org/publicdomain/zero/1.0/) applies to the data made available in this article, unless otherwise stated in a credit line to the data. 

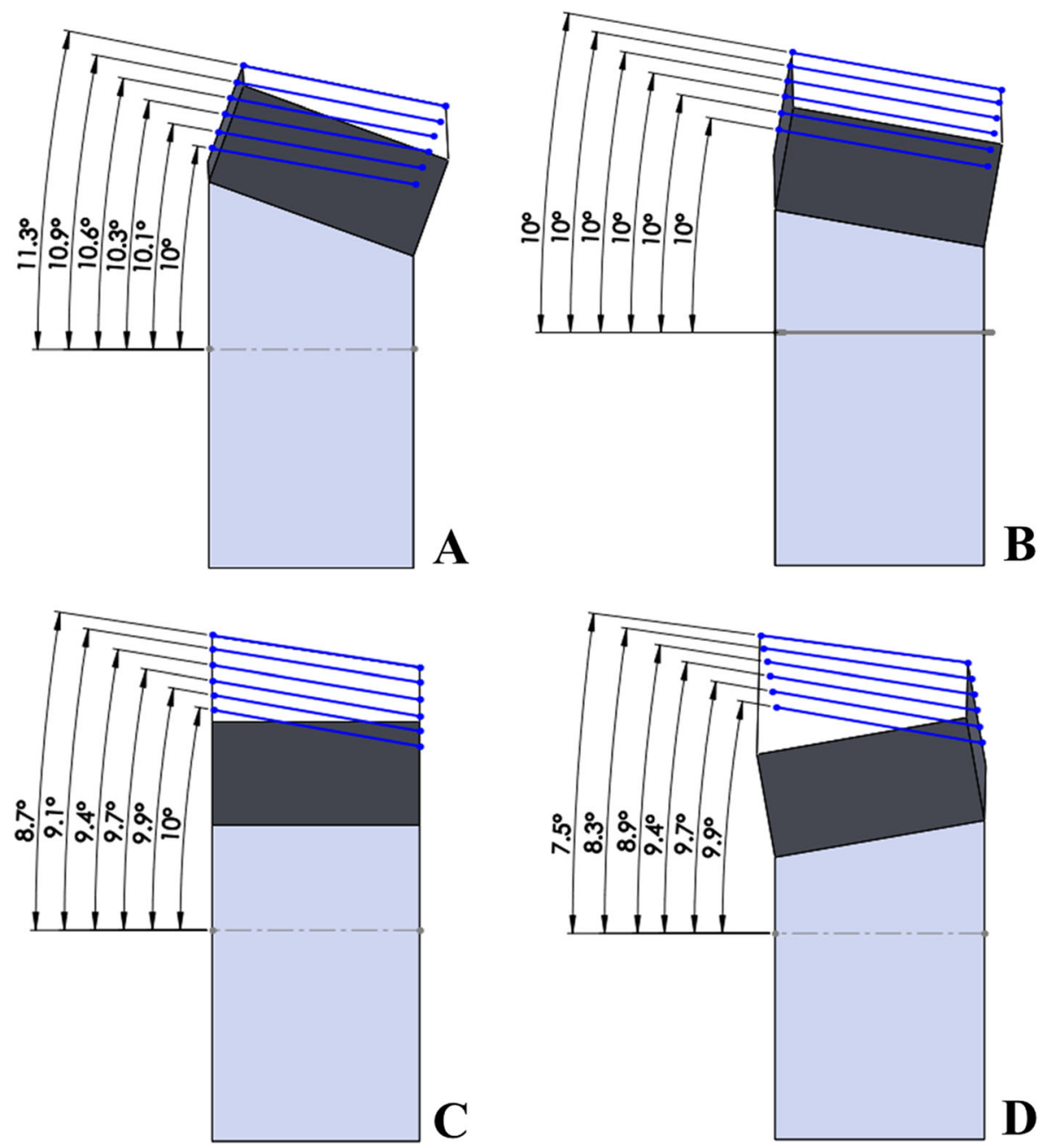

Fig. 3 Changes in posterior slope during virtual simulation with SPOI $20^{\circ}(\mathbf{a}), \mathrm{SPOI} 10^{\circ}(\mathbf{b}), \mathrm{SPOI}: 0^{\circ}(\mathbf{c})$, and $\mathrm{SPOI}-10^{\circ}(\mathbf{d})$ 